\title{
Peran dan fungsi prostesis dalam fungsi sistem stomatognatik Role and function of prosthesis in the stomatognathics system function
}

\author{
Muslich Mahmud, Jeffrey \\ Program Studi Kedokteran Gigi \\ Fakultas Kedokteran Universitas Ahmad Jani \\ Cimahi-Bandung, Indonesia
}

\begin{abstract}
Do literary study of the role and function of the prosthesis in overcoming or restoring function stomatognathic system cannot function optimally. There is a variety of lost body parts due to illness or accident requiring abnormalities restoration or rehabilitation with artificial materials. To overcome this thing, there are a variety of prosthesis, the dental prosthesis, maxillofacial prosthesis, and supporting prosthesis (ancillary prosthesis). The analysis focused on overcoming tooth loss causes shortening jaw arch and various maxillofacial abnormalities using compatible materials, a variety of complications and their consequences. Data showed that the loss of the system's structure can disrupt stomatognathic masticatory function, esthetics, phonetics, swallowing and breathing. Installation of a removable prosthesis, partial or full will improve the efficiency of mastication and chewing ability, a greater increase in fixed prostheses and implants. Esthetic and satisfaction very disturbed due to missing front tooth with a large variation of subjectivity for the age group, social, cultural, regional and state. Generally, patients are less affected by the phonetic compared to mastication. Although not fully, function prosthesis can replace missing teeth and the surrounding tissue, and keep tissue health of the stomatognathic system. It was concluded that prosthesis can help, restore and maintain function of stomatognathic system, namely the mastication, esthetics, phonetics, swallowing and breathing.
\end{abstract}

Key words:stomatognathic system, mastication, esthetics, phonetics, swallowing, breathing

\begin{abstract}
ABSTRAK
Dilakukan studi kepustakaan tentang peran dan fungsi prostesis dalam membantu atau mengembalikan fungsi sistem stomatognatik yang tidak dapat berfungsi maksimal. Terdapat bermacam-macam kehilangan bagian tubuh akibat penyakit kelainan atau kecelakaan yang memerlukan restorasi atau rehabilitasi dengan bahan artifisial. Untuk mengatasi hal ini terdapat bermacam-macam prostesis, yaitu prostesis gigi, prostesis maksilofasial, dan prostesis pendukung (ancillary prosthesis). Analisis dititikberatkan pada kehilangan gigi yang menyebabkan pemendekan lengkung rahang dan berbagai kelainan maksilofasial menggunakan bahan kompatibel, berbagai komplikasi dan akibatnya. Diperoleh data bahwa kehilangan struktur sistem stomatognatik dapat mengganggu fungsi pengunyahan, estetik, fonetik, penelanan dan pernapasan. Pemasangan prostesis lepasan baik sebagian maupun lengkap akan meningkatkan efisiensi pengunyahan dan kemampuan pengunyahan, peningkatan lebih besar pada prostesis cekat dan implan. Estetik dan kepuasan sangat terganggu akibat gigi depan hilang dengan variasi subjektivitas yang besar untuk kelompok umur, sosial, budaya, daerah dan negara. Umumnya pasien tidak begitu terpengaruh oleh fonetik dibandingkan dengan pengunyahan. Walaupun fungsi prostesis belum sepenuhnya dapat mengganti gigi dan jaringan sekitarnya, dan mempertahankan kesehatan jaringan dari sistem stomatognatik. Disimpulkan bahwa prostesis dapat membantu, mengembalikan dan mempertahankan fungsi sistem stomatognatik, yaitu fungsi pengunyahan, estetik, fonetik, penelanan dan pernapasan.
\end{abstract}

Kata kunci: sistem stomatognatik, pengunyahan, estetik, fonetik, penelanan, pernapasan

Koresponden: Jeffrey, Program Studi Kedokteran Gigi, Fakultas Kedokteran Universitas Ahmad Jani. J1. Terusan Jend. Sudirman, PO Box 148, Cimahi, Jawa Barat 40533, Indonesia.E-mail: jeffrey_dent2000@yahoo.com 